Б. А. Савчук, В. А. Арсірій

Одеська державна академія будівництва та архітектури, вул. Дідріхсона, 4, Одеса, 65029, Україна

$\bowtie$ E-mail: vasily.arsiry@gmail.com ORCID: 0000-0003-3617-8487

\title{
Реконструкція турбін методом аналогового моделювання, зображення структури потоку і вдосконалення частин потоку
}

\begin{abstract}
В статті розглянуто проблеми значних втрат енергї для подолання гідравлічного опору, представлені результати діагностики структури потоку при русі в елементах турбін, а також варіанти удосконалення геометріі частин потоку. Головною проблемою гідродинаміки є великі витрати енергї на подолання гідравлічних опорів. Крім витрат енергії, опір викликають пульсації $і$ як наслідок зменшення діапазону регулювання продуктивності обладнання, є причинами шуму, вібрачії та інших негативних явищ. Перераховані недоліки обумовлені недосконалістю (нерідко навіть примітивністю) геометрії проточних частин. Проблеми гідродинаміки пов'язані з тим, щзо процеси руху рідин і газів практично недоступні для візуальних досліджень. Досі гідродинаміка заснована на парадигмі турбулентності, яка асоиіюється як «хаос». Тому, довідники і каталоги, які використовують при проектуванні гідравлічних систем, невиправдано «прийняли» технологічно прості проточні частини поворотів, колекторів, трійників, і ін. i, відповідно, високі значення їх гідравлічних опорів. Коригування геометрії проточних частин з метою вдосконалення структури потоку забезпечує зниженням опору в $n$ 'ять разів $i$ більше. Високий ступінь організаиії гідравлічних потоків може бути основою для створення нової парадигми «структури потоків», яку доцільно використовувати при проектуванні обладнання та гідравлічних систем. Однак, динамічні прочеси в проточних частинах сьогодні характеризуються тільки величинами опорів, інші показники ефективності при проектуванні не використовуються. Досвід позитивних результатів зниження опору при реалізаиії проектів реконструкиії, коли збільшується продуктивність системи з одночасним зниженням початкового тиску, призводить до зниження ККД насосів, вентиляторів, компресорів. Отже ККД основного обладнання системи і опір проточних частин по різному характеризують показники ефективності енергетичних процесів.
\end{abstract}

Ключові слова: Турбіни; Моделювання; Структура потоку; Удосконалення геометрії

(C) The Author(s) 2018. This article is an open access publication

This work is licensed under the Creative Commons Attribution 4.0 International License (CC BY) http://creativecommons.org/licenses/by/4.0/

\section{1. Вступ}

Сучасне обладнання, робота якого пов'язана з рухомими рідинами і газами (насоси, турбіни, трубопроводи, відводи та інш.), мають низьку ефективність через значні втрати енергії для подолання гідравлічного опору. Крім втрат енергії, опір викликає пульсації i, як наслідок, зниження діапазону регулювання потужності обладнання. Також підчас руху рідин і газів, опір викликає шум, вібрацію та інші негативні явища. Вищезазначені недоліки пояснюються недосконалою (іноді навіть примітивною) геометрією проточних частин.

Причиною цих проблем є оптична прозорість рідин і газів (вода, повітря, нафта і газ), тому їх структура потоку недоступна для вивчення. Поки що механіка рідин не має законів, що описують організацію гідродинамічної структури і проектування оптимальних проточних каналів. Турбулентність вважається складним рухом дисипативних середовищ і пов'язана 3 хаосом [1]. Гідравлічні довідники, які використовуються для проектування обладнання, мають невиправдано прості технологічно прохідні канали для труб, відводів, клапанів. Сучасні уявлення про рух рідин і газів базуються на концепції турбулентності [2]. Рівняння, що описують турбулентний потік, передбачають лише усереднені параметри швидкості i тиску. Візуальна діагностика потоків відіграє особливу роль у визначенні та аналізі параметрів обладнання. Завдання візуальних досліджень - показати картину структури потоку.

На рисунку 1 представлені результати візуальних досліджень структури потоків в затопленому просторі, найбільш відомі в літературі [3]: ламінарний рух, в якому видно парову лінію поперечних структур (рисунок 1 , а) та турбулентний потік, де видно великомасштабні ділянки в поздовжньому розрізі структур (рисунок 1 , б). Такий образ турбулентного потоку, отриманий Рошко в 1976 році, дозволив змінити картину турбулентності як хаотичного руху «певного хаосу» [3]. Вже існують моделі, які описують можливість виникнення структури потоку в пограничному шарі, запропоновані Тейлором і Колмогоровим. Однак представлена розмірність структур потоку, що зароджуються, $\epsilon$ безрозмірним параметром, і враховується виходячи 3 розмірів приграничного шару, значення якого важко виміряти. 


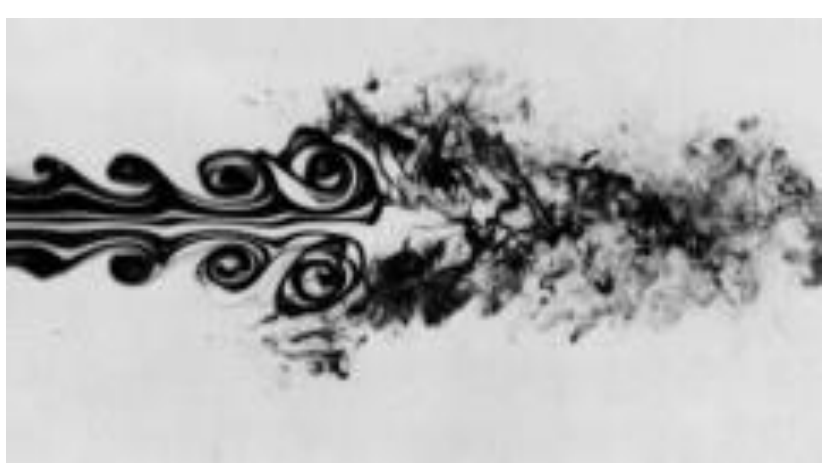

$a$

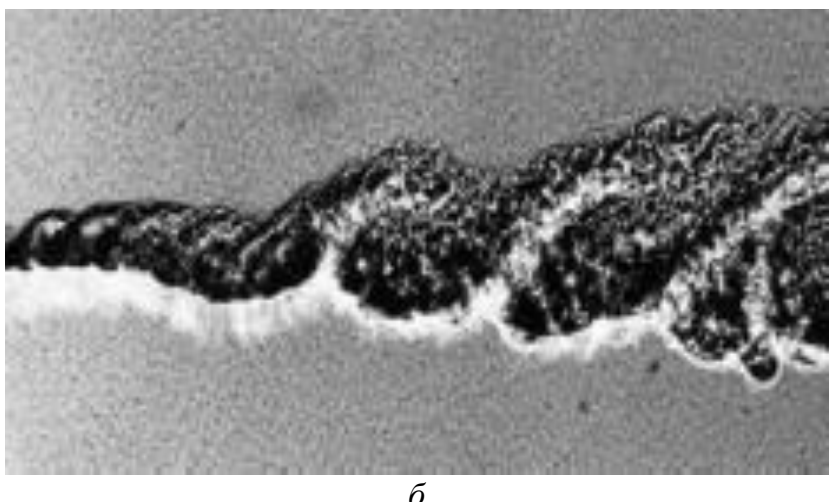

Рисунок 1 - Візуалізація потоків в затопленому просторі: $а$ - димова візуалізачія , б-іскровий метод.

Існуючі моделі турбулентності та моделі, представлені на рисунку 1, дають мало інформації про структуру потоку і не підходять для вирішення технічних завдань.

\section{2. Метод зображення діагностики структури по- току}

У статті представлено метод зображення діагностики структури потоку (ЗДСП). Цей метод дозволяє отримати інформацію про структуру потоку, яка підходить для вирішення прикладних завдань. Висока інформативність ЗДСП пов'язана 3 використанням оптично активної рідини (ОАД - оксиду ванадію $\mathrm{V}_{2} \mathrm{O}_{5}$ ) при зміні поляризованого світла за значеннями оптичної щільності (інтенсивний білий або сірий) в кожній точці потоку в залежності від гідродинамічних напруг (градієнти швидкості або тиску). Спеціальні фізичні моделі з характерними перерізами проточних каналів зроблені для візуальних досліджень, в яких ОАД рухається із заданими параметрами згідно числу Рейнольдса. Процес руху реєструється як зображення і аналізується. Світліші області характеризуються позитивними градієнтами швидкості, темні - негативними градієнтами швидкості. Таким чином, зображення характеризуються полем миттєвих значень швидкості. На рисунку 2 представлено результати зображення діагностики структури потоків в затопленому просторі [4]

Візуальні дослідження на фізичних моделях експериментально показали, що рух рідин і газів має стійку структуру.

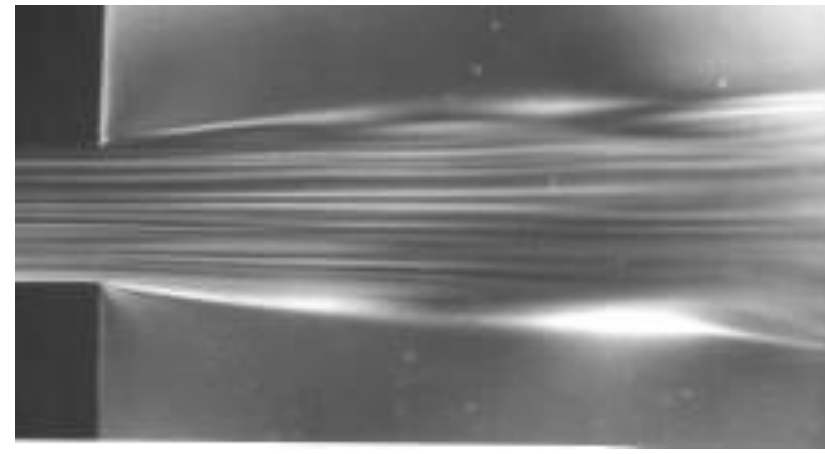

$a$

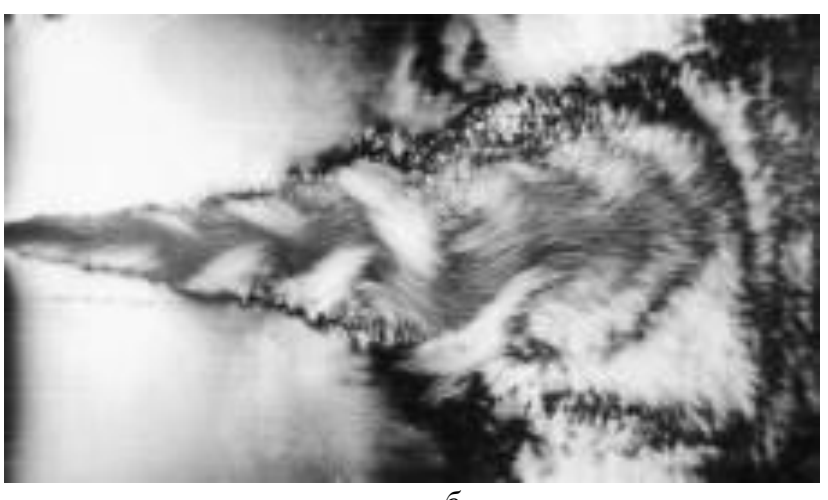

6

Рисунок 2 - Візуальна діагностика структури потоку: $a$-ламінарний режим, б-турбулентний режим.

Ламінарний режим характеризується регулярним розподілом структури в поперечному перерізі (рисунок 2, а). Структури вздовж потоку (або проточних ліній) мають ідентичну поглинаючу здатність, отже, вони мають постійну швидкість. Однак в поперечному перерізі шари потоку мають гармонійну зміну поглинання, отже, зміна швидкості росту по потоку має хвильовий характер. Турбулентний режим характеризується дискретними (когерентними) оптично однорідними структурами і вихровими областями в поздовжньому розрізі потоку (рисунок 2, б). Стійкий характер структури потоків (СП) дозволив розробити і провести серію гідравлічних експериментів.

\section{3. Результати моделювання. СП-технологія для проектування проточних каналів}

Способи застосування ЗДСП показані на прикладі проектування оптимального проточного потоку у відводі на $90^{\circ}$. На рисунку 3 показана структура потоку у відводі з рівними внутрішніми і зовнішніми кутами або радіусами заокруглення. Щоб охарактеризувати оптимальний рух рідин або газів, введемо термін «гідравлічна ефективність проходу потоку», який можна застосовувати до гідравлічного або аеродинамічного обладнання. Для цього ми використовуємо відоме значення коефіцієнта споживання $\mu$, яке може бути розраховано на основі значення опору $\zeta$.

$$
\mu=\frac{1}{\sqrt{1+\zeta}}=Q_{\mathrm{a}} / Q_{\mathrm{t}}
$$

де $\mu$ - коефіцієнт споживання; $\zeta$ - гідравлічний опір; $Q_{\mathrm{a}}-$ фактичне споживання; $Q_{\mathrm{t}}-$ теоретичні витрати. 


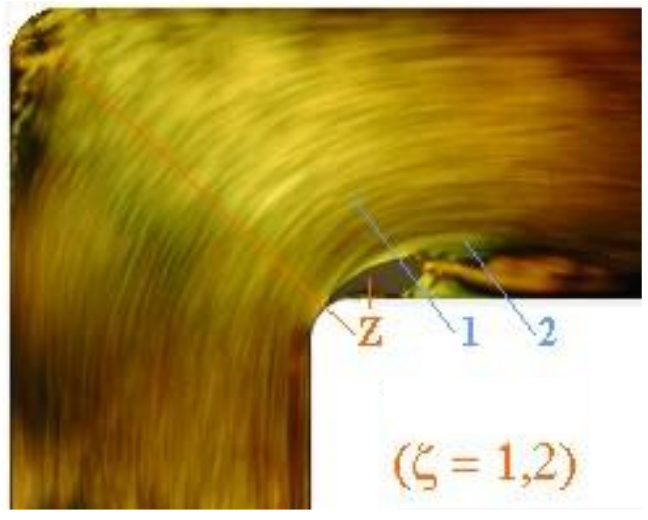

$a$

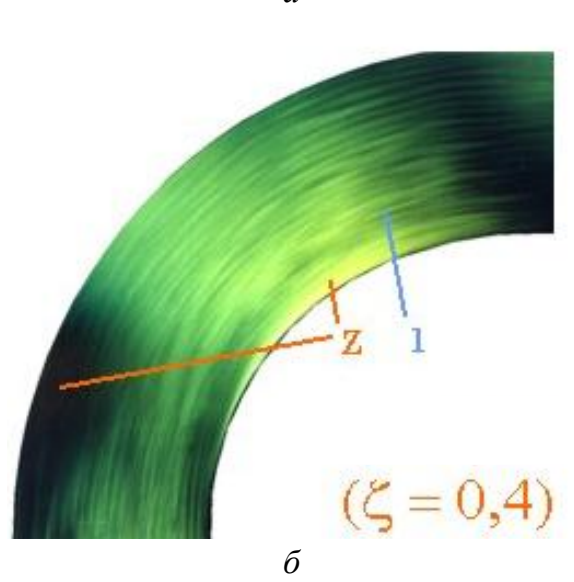

Рисунок 3 - Структура потоків у відводі на 90: $a$ - "вигин" $\mu=0,68 ; \sigma-$ "боковий" $\mu=0,85$

Таким чином, ефективність руху рідин і газів в проточних каналах може бути охарактеризована співвідношенням фактичного споживання $Q_{\mathrm{a}}$ до теоретичної витрати $Q_{\text {t }}$. Якщо значення гідравлічного опору $\zeta=1,2$, то ефективність руху рідин або газів в «відводі» становить $\mu=0,68$. Ілюстрації демонструють причини такої низької ефективності. Розсіяні області, в яких потік виходить зі стін Z, є зонами максимальних втрат енергії. Хаотично розташовані поперечні структури, представлені у вигляді поточних ліній 1, і структури поздовжнього потоку, представлені у вигляді однорідних оптичних зон 2, не сприяють організованому руху в проточному каналі відводів.

Метод ЗДСП дозволяє значно підвищити ефективність руху у відвід $[4 ; 5 ; 6] .3$ цією метою структура потоку оптично активної рідини розглядається в спеціально розробленої моделі так званого «чорного ящика» (рисунок 4, а).

Прохід потоку «чорного ящика» забезпечує задані вхідні і вихідні розміри каналу, беручи до уваги радіус потоку відведення в затопленому просторі. Спеціально збільшені розміри прохідного каналу в «чорному ящику», між першою і останньою секціями, дозволяють найбільш оптимально змінювати трубу відведення. Отриманий образ структури потоку в «чорному ящику» дає інформацію для вирішення проблеми визначення оптимальних меж і геометрії проточної труби (рисунок
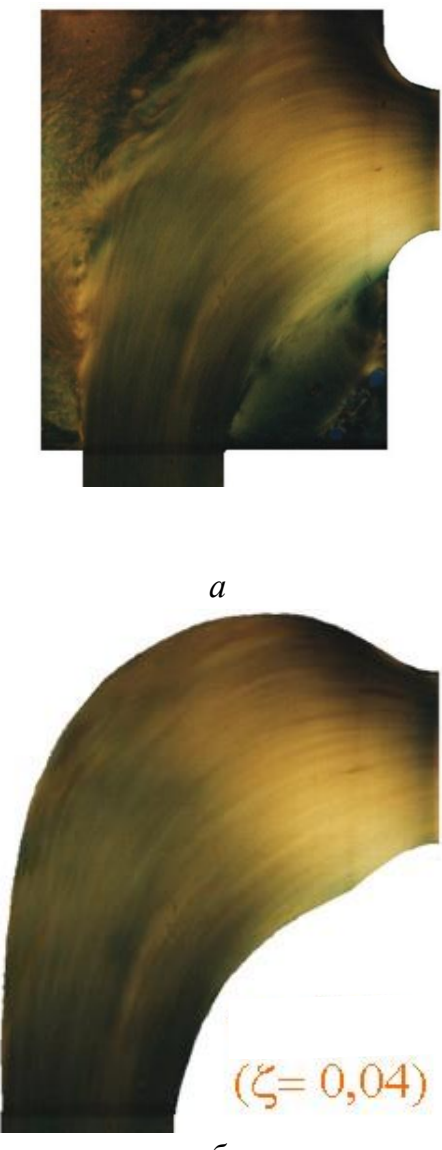

$\sigma$

Рисунок 4 - Проектування оптимального відводу на

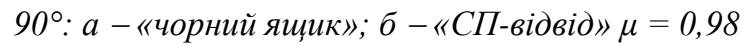

4, б).

При проходженні потоку через відведення на 90, яке розроблено з використанням методу структури потоку в поперечному і поздовжньому перетинах, ефективність транспортування рідин і газів збільшується до $\mu=0,98$.

\section{4. Висновки}

В роботі сучасного енергетичного обладнання $\epsilon$ ряд серйозних проблем. Більшість з цих проблем, прямо або опосередковано, пов'язані зі складною, а іноді і примітивної геометрією частин потоку. Основною причиною цих проблем є оптична прозорість рідин і газів, тому їх структура потоку недоступна для вивчення. У зв'язку з цим, сучасне обладнання має низьку ефективність через значні втрати енергії для подолання гідравлічного опору.

Інноваційний метод зображення діагностики структури потоку (ЗДСП) може виявити раніше невідому інформацію про закони руху рідин і газів. Нова модель «структури потоку» замінює стару модель «турбулентності», де хаос «середніх параметрів» був перешкодою у вирішенні проблем енергозбереження. Для реалізації проектів з удосконалення обладнання необхідно розробити нові показники ефективності обладнання і систем, які повинні стимулювати економічну ефективність 
процесів. Використовуючи закони організації структури потоку, покращуючи поточні деталі, ми можемо розробити нове або поліпшити існуюче обладнання 3 можливістю досягнення нового рівня енергії, розмірів, акустики, вібрації, викидів та інших характеристик. Запропонована технологія, заснована на зображенні діагностики структури потоку, дає можливість розробляти нове енергетичне обладнання $з$ високою ефективністю і допомагає вирішувати складні проблеми енергозбереження.

\section{Література}

1. Brian J. Cantwell. Organised motion in turbulent flow. / Ann. Rev. Fluid Mech. - 1981. - Vol. 13. - P. 457-515. 2. Idelchik I.E. Shteynberg M.O. Handbook of hydraulic resistance. - Engineering. -1998 . -672 p.
3. Van Dyke. An album of fluid motion. / Stanford, California: The Parabolic Press.

4. Arsiry V.A. Improvement of main and auxiliary equipment of heat and nucleus energy on the base of the diagnostics of the streams. / The dissertation of doctor of the technique science. Odessa National Polytechnic University, Odessa. - 2004.

www.disslib.org/sovershenstvovanye-oborudovanyjateplovykh-y-jadernykh.html

5. Maisotsenko V. S., Arsiri V. A. Method of determining for working media motion and designing flow structures for same // PST 5.812.423 USA 3/4 Publ. - 1998.

6. Maisotsenko V. S., Arsiri V. A. Method of restricted space formation for working media motion. // PST 5.838.587 USA 3/4 Publ. - 1998 .

\title{
Reconstruction of turbines by analog modeling, image structure of flow and improvement of parts of the flow
}

\author{
B. A. Savchuk, V. A. Arsiry \\ Odessa State Academy of Civil Engineering and Architecture, 4 Didrikhsona str., Odessa, 65029, Ukraine \\ $\triangle$ E-mail:vasily.arsiry@ gmail.com ORCID: 0000-0003-3617-8487
}

\begin{abstract}
The problems of significant energy losses for overcoming the hydraulic resistance are considered in the article, the results of the flow pattern diagnostics when moving in turbine elements are presented, as well as options for improving the geometry of the flow parts. The main problem of hydrodynamics is the substantial energy losses in order to overcome hydraulic resistance. Except for substantial energy losses the resistances cause pulsations and, as a consequence, a reduction in the range of capacity regulation of the equipment, are the cause of noise, vibration and other negative phenomena too. These shortcomings are due to imperfection (often even primitive) of the geometry of the flow parts. The problems of hydrodynamics are related to the fact that the processes of motion of liquids and gases are practically inaccessible to visual studies. Until now, hydrodynamics is based on the paradigm of turbulence, which is associated as chaos. Therefore, reference books and catalogs that are used in the design of hydrodynamic systems, unjustifiably "legitimized" the technologically simple flow parts of turns, manifold, tees, etc. and high values of their hydraulic resistances, respectively. The geometry healing of flow parts with the purpose of improving the flow structure provides reduction of resistance 5 times or more. A high degree of hydraulic flows organization can be the basis for creating a new paradigm of "flow structure", which is useful to use in the design of equipment and hydraulic systems. However, the dynamic processes in the flow parts are characterized only by the resistance value. Other measures of efficiency are not used when designing. The experience of positive results of reducing resistance during the implementation of reconstruction projects, when the system's productivity increases with simultaneous reduction of the initial pressure leads to a decrease of efficiency pumps, fans, compressors. That is, the efficiency coefficient of the main equipment of the system and the resistance of the flow ranges characterize differently the efficiency indicators of the energy processes.
\end{abstract}

Keywords: Turbomachines; Modeling; Flow structure; Geometry improvement

\section{References}

1. Brian J. Cantwell. (1981) Organised motion in turbulent flow. Ann. Rev. Fluid Mech., vol. 13, 457-515.

2. Idelchik I.E. Shteynberg M.O. (1998) Handbook of hydraulic resistance. Engineering, 672 p.

3. Van Dyke. An album of fluid motion. Stanford, California: the Parabolic Press.

4. Arsiry V.A. (2004) Improvement of main and auxiliary equipment of heat and nucleus energy on the base of the diagnostics of the streams. The dissertation of doctor of the technique science. Odessa National Polytechnic University, Odessa. www.disslib.org/sovershenstvovanye-oborudovanyjateplovykh-y-jadernykh.html

5. Maisotsenko V. S., Arsiri V. A. (1998) Method of determining for working media motion and designing flow structures for same. PST 5.812.423 USA 3/4 Publ.

6. Maisotsenko V. S., Arsiri V. A. (1998) Method of restricted space formation for working media motion. PST 5.838.587 USA 3/4 Publ.

Received 09 February 2018 Approved 06 March 2018 Available in Internet 30 March 2018 